\title{
Legitimizing policies: How policy approaches to irregular migrants are formulated and legitimized in Scandinavia
}

\author{
Martin Bak Jorgensen \\ Institute for Culture and Global Studies, Aalborg University, martinjo@cgs.aau.dk
}

The focus of this article is on representations of irregular migration in a Scandinavian context and how irregular migrants are constructed as a target group. A common feature in many (Western-)European states is the difficult attempt to navigate between an urge for control and respecting, upholding and promoting humanitarian aspects of migration management. Legitimizing policies therefore become extremely important as governments have to appease national voters to remain in power and have to respect European regulations and international conventions. Doing so raises questions of social, political and economic rights, of moral obligations, of sovereignty, and of equity, as well as of how to define target groups and legal and categorical statuses into the debates. Having a backdrop in the theoretical framework of Carol Bacchi, Anne Schneider and Helen Ingram and Giorgio Agamben, this article looks at how policy problematizations and constructions of target populations guide and legitimize particular policy approaches and may end up marginalizing and excluding groups in society and ultimately become a challenge for democracy.

Keywords: policy making, irregular migration, target populations, citizenship, democracy, categorizations, Scandinavia

\section{Dansk abstract: Legitimering af politik: Hvordan politiske tilgange til irregulære indvandrere formuleres og legitimeres i Skandinavien}

Fokus i denne artikel er på reprosentationer af irregulor migration i en skandinavisk kontekst og hvordan illegale indvandrere er konstrueret som målgruppe. Et foelles trak i mange vesteuropoiske nationalstater er det svore fors $\emptyset g$ på at navigere mellem kontrol og samtidig respektere, forsvare og fremme humanitore aspekter af migrationsstyringen. At legitimere den givne politik er derfor blevet sardeles vigtigt fordi regeringerne er nødt til at formilde de nationale indvandringsskeptiske valgere for at forblive ved magten og er nødsaget til at respektere europaiske regler og internationale konventioner. Dette italesœtter en diskussion om sociale, politiske og økonomiske rettigheder, af moralske forpligtelser, af suvercenitet, af at definere målgrupper og juridiske statuskategorier $i$ debatterne. Artiklen har baggrund $i$ en teoretisk ramme som er udstukket af Carol Bacchi, Anne Schneider, Helen Ingram og Giorgio Agamben. Artiklen ser på, hvordan politiske problematiseringer og konstruktioner af målgrupper vejleder og legitimerer bestemte politiske strategier og kan ende med at marginalisere og udelukke grupper $i$ samfundet og $i$ sidste ende blive en udfordring for demokratiske principper som sådan. 
Keywords: policy making, irregulær indvandring, målgrupper, medborgerskab, demokrati, kategoriseringer, Skandinavien

\section{Introduction}

Irregular migration has long been perceived and conceptualized as an eminent social problem in the European Union and many Member States. ${ }^{1}$ The perceived danger might be much greater than the actual number would give reason for (Koser 2005). Nevertheless, several policy developments have been initiated to combat the real problem and perceived threat that irregular migration puts forth. Although irregular migration has been considered a lesser problem in Scandinavia, it is still a policy issue that the countries have had to deal with (Jørgensen \& Meret 2012). Irregular migration has been on the political agenda for more than a decade in Sweden but only recently so in Denmark, where the issue more or less has been ignored. In Norway, the political debate and decision making on irregular migration has been influenced by concrete events, such as the controversial Maria Amelie case. ${ }^{2}$ This article analyses the representations of irregular migration in the policy debates on irregular migration in Scandinavia, with a specific focus on how irregular migrants are constructed as a target group giving way to a discussion of the policy frameworks addressing the issue in Scandinavia.

The article has an explicit normative agenda. Following the work of Carol Bacchi (2009), I presume that some policy representations benefit members of some groups and harm others. Having a poststructuralist point of departure, this implies that no categories or concepts can be regarded as value-free and uncontested (2009: 31-32). Anne Schneider and Helen Ingram (1997) have drawn particular attention to the instrumental and symbolic messages that these policy target group constructions convey. Subsequently, these constructs can have real effects on the social position, behaviour and public perceptions of specific social groups. Gaps between the constructed deserving and undeserving groups becomes larger as the governments want to bind powerful groups to the state (Schneider \& Ingram 1997).

This article argues that the social constructions of target groups that carry negative messages will undermine the quality of effective democracy. Schneider and Ingram (2007) have described such policy designs as 'degenerative': «systems [that] are characterized by an unequal distribution of political power, social constructions that separate the «deserving» from the «undeserving», and an institutional culture that legitimizes strategic, manipulative, and deceptive patterns of communication and uses of political power» (ibid: 102). This implies that policy tools marginalize and exclude groups in the society and appear unable to resolve the underlying policy problems that they are supposed to address. In such a system, group-based political inequalities and divisive policy designs reinforce in ways that threaten democracy (Soss 2005: 293). They convey different messages about how the government works, how it responds and how it values the particular target group. 
The article does not seek to provide a stringent empirical case study. It seeks instead to discuss the issue of irregular migration from different theoretical perspectives. This is done first by engaging in a theoretical discussion of how irregular migration is represented as a particular type of social problem in Scandinavia, demanding policy action (section one); second, through a discussion on categorization - what is in a name and how does a particular status category legitimize policy actions (section two) and third, through an empirically based discussion on irregular migration in the three Scandinavian countries (section three). The article concludes that irregular migration is situated in a discussion on national discretion and sovereignty vis-à-vis respecting human rights, which can be recognized also in the ways that the countries deal with related issues of migration, asylum and integration and ultimately issues pertaining to national identity. For all three countries, we can detect a turn towards more restrictive policy frameworks.

\section{Framing: What is the problem supposed to be? Theoretical reflections}

Bacchi (2009) has developed an approach to policy analysis focusing on the construction of political problems, which is heavily inspired by Michel Foucault. The approach moves beyond the conventional understanding of the term policy where policies are interpreted as responses to a problem, thereby implying that something needs to be fixed. Policies consequently are instruments for solving social problems. However, as Bacchi sees it, policies are not exogenous, existing outside the policy-making process. Rather they are endogenous and shaped by and created within the policy-making process (Bacchi 2009: $\mathrm{x})$. Policies thereby give shape to problems rather than addressing them. For Bacchi, this implies that we are governed by problematizations rather than through policies (Bacchi 2009: 31). Studying problematizations implies looking at the assumed problem, that which 'needs to be fixed', by looking at the political instruments, legislative measures and action plans developed to tackle the problem. For this purpose, she puts forth concrete analytical questions that pay attention to different aspects of the problem representation and include questions like: How is the problem presented in a specific policy? What presuppositions underlie the problem formulation? What is assumed and taken for granted, and what is the conceptual logic supporting the problem formulation? What effects are produced by this representation of the problem?

So, for example, looking at irregular migration from Bacchi's perspective (to elaborate this point), we can say that migrants only become irregular if defined as such by immigration laws and regulations in policy and legislation. Restricting migration laws may thus obviously create irregularity. It is not necessarily the person that changes but his or hers position on the labour market. Laws may change their status and hence have the effect of creating illegality (cf. Guild 2004). Put differently, irregular migration is not simply a policy problem to be solved, but a problem that has been constructed as a specific type of problem by policy makers. 
According to Bacchi's framework, then, policies are not driven by social change but should instead be seen as the outcome of deliberate assumptions about a given social phenomenon or group that has physical consequences - or what Bacchi terms 'lived' effects. It is therefore of vital importance to examine how a given representation of a presumed 'problem' is constructed, and what kind of effect a particular problematization has for the subjects who are constructed within the problematization.

Although there are in principle numerous competing constructions of a particular 'problem', governments stand in a privileged position because their particular problem constructions tend to 'stick' (Bacchi 2009: 33). Their versions are constituted in policies, legislation and technologies used to govern. They can decide when an issue demands attention and when it doesn't.

Policies are based on particular mechanisms of exclusion and inclusion. Schneider and Ingram conceptualize the target group constructions in terms of the negative or positive messages they convey as well as in terms of whether they define the different groups as being either powerful or weak (Schneider \& Ingram 1997: 113). Advantaged target populations in their framework have significant political power resources and are characterized as deserving groups. Dependents have less political power resources but are still constructed as deserving in a moral sense although they are regarded as helpless and in need of correction and discipline. Contenders have resources that compare to that of advantaged groups but are not regarded as deserving. Deviants constitute weak and powerless groups who are negatively constructed as undeserving and of no value for society (Schneider \& Ingram 2005: 17). Burdens are oversubscribed and benefits undersubscribed for the undeserving groups and vice versa for the deserving groups. Governments have bigger gains and political opportunities when applying negative measures than offering positive treatment. To appease skeptical voters, governments are therefore inclined to call for further control and sanctions rather than addressing the problem with alternative policy instruments. Schneider and Ingram argue that «[m] uch of the dynamics of policy design for dependent people hinges on separating the deserving from the undeserving» (1997: 124).

The particular target group construction legitimates the chosen tools, rules and rationales for delivering benefits and burdens. In the case of irregular migrants, the target group constructions are fairly simple from the governments' perspectives. In Denmark, for instance, irregular migrants have violated the law and committed a criminal act by entering the country without the necessary permits and should be deported from the country again; hence, there is a preference for the notion 'illegal' migrants. The dominating problem with representation found in most immigrant receiving countries in the Western world is based on negative representations. Irregular immigrants are perceived to constitute a threat to the established political order, to the labour market arrangements, to public health and several other security related issues. Often, however, reality is far more complex than this sketchy outline. Despite having entered a country without the necessary permits - or having overstayed their legal stay, which is the most common route into irregularity - irregular migrants still have specific rights anchored in the human rights conventions. How these rights should be interpreted and implemented dif- 
fers within the European countries. Moreover, irregular migrants are not always aware of when they go from one status to the other or can be exploited by employers. Au-Pair girls in Denmark working more than the allowed hours, for instance, are put in an irregular labour market position by their host-family and not necessarily by own intention.

Governments and authorities are forced to act to maintain integrity and appease skeptical parts of the population, that is, the electorate (Jørgensen \& Meret 2010). The actions are only legitimized through the particular representation and they do not necessary comply with international rights located above the nation-state.

\section{Consequences of target group constructions - a normative perspective}

Increasingly advanced liberal democracies have made use of illiberal means to reach their goals as for instance combatting irregular migration (Triadafilopoulos 2011) - deporting people without having done a proper case investigation or harshening life-conditions in detention centres as preventive measures. The discursive coupling of processes of migration with potential terrorism have legitimized illiberal means and undermined democracy - for some at least. As Stephen Castles has argued, refugees post 9/11 have been represented as a serious, transnational threat against national security although none of the perpetrators behind the act were refugees or asylum seekers (Castles 2003). Persons and groups previously met with respect and dignity are now constructed as a deviant dangerous target group. Contrarily, states are more eager to receive migrants making an economic contribution to society while confining marginalized and vulnerable outsiders to, in Bill Jordan and Franck Düvell's words, «impoverished and excluded communities of fate» (Jordan \& Düvell 2003). In a similar reading, Zygmunt Bauman has included irregular migrants among the 'human trash' created by globalization - constituting 'wasted lives' (Bauman 2004). This combination of market-driven regimes for migration management (Jordan \& Düvell 2003) with the transformation and retrenchment of the social state (Bauman 2004) leads to what Loïc Wacquant (2009) has described as a punishment of the poor. This entails strong mechanisms of exclusion strengthening the gaps between deserving and undeserving groups (Schneider \& Ingram 1997). The dismantling of the social-state requires a new modus of legitimacy serving as the basis for governance.

To sum up, categories are not innocent. Categories are embedded in problem understandings building on particular diagnoses of the perceived problems. Putting forth a diagnosis also includes a prognosis of what should be done to solve the alleged problem. How problems firstly are constructed as problems and secondly how they are framed have a crucial impact on the policy design that is developed to tackle the problems.

\section{Naming: What's in a name?}

Giorgio Agamben has made a powerful analysis of the state responses in times of political crisis (perceived or real) (Agamben 1995, 2005). In State of Exception, he examines the 
power structures governments employ in times of perceived crisis. The problematization of irregular migration as something uncontrollable and dangerous in combination with potential terrorism and criminal activities becomes an emergency condition. Within such emergency conditions, Agamben identifies increased extension of power as 'states of exception', where citizenship and individual rights can be diminished and rejected in the process of claiming this extension of power by a government. The problem of irregular migration hence becomes an emergency that legitimately can be dealt with outside normative legal circumstances. Agamben analysed the treatment of the so-called enemy combatants captured in Afghanistan and sent to Guantánamo Bay without trials to illustrate the state of exception, but the issue of irregular migration and treatment of irregular migrants could easily be used to display the same logic. Most national legislations will hold the possibility to suspend the law in a state of emergency. However, Agamben shows how it becomes a permanent condition and turns into a state of exception. The moral problem is, of course, if the emergency is perceived and not real, and thereby illegitimate. This problem connects to Phil Triadafilopoulos' argument stated above - that advanced liberal democracies increasingly make use of illiberal means to reach their goals. Danish legislation has, for instance, been criticized by the UNHCR several times for deporting rejected asylum seekers to non-safe areas (UNHCR 2010; see also Amnesty International 2010).

Agamben's conceptual framework and normative point of departure has been used in a Scandinavian context also (e.g. Hjelde 2010; Khosravi 2006; Kjærre 2010; Stenum 2010), especially in relation to issues of access and right to health. In a study on irregular migrants' life conditions in Oslo, Karin Hersløf Hjelde argues that although irregular migrants are excluded from all the elements that define human life and human rights «they do not cease being human, they are only dehumanised» (Hjelde 2010: 331). Their lives are characterized by having no work rights and access to health services and living in conditions where they are stripped of their civil, social and political rights. As argued above, the deliberate use of the category 'illegal migrant' (compared to irregular migrant, sans-papiers, undocumented, paperless etc.) can be seen as a policy tool in constructing such migrants as undeserving, deviant, unentitled ( $c f$. Schneider \& Ingram) but can also be read as the deliberate choice of placing the migrants outside the law, outside the norms (how people should be treated) - the legal citizens. We find stories on irregular migrants living without any security, being exploited in all the three Scandinavian countries (Thomsen et al. 2010).

Agamben uses the notion homo sacer about the individual residing outside the normal juridical space (1995). Homo sacer means bare life, a person stripped of all rights. It is a depoliticized life that stands in contrast to citizenship. The notion stems from Roman law where it defines a person who is banned and may be killed by everyone. He has no political or religious value anymore. Again the homo sacer can be related to the issue of irregular migration. The one stripped of rights and excluded from broader citizenry. Although a large group of non-citizens in Europe and other liberal democracies enjoy the same social and economic rights, as well as some of the political rights as citizens (e.g. 
FRA 2011), they enjoy the least amount of rights and in some situations are stripped of basic rights such as access to health treatment.

Excluding the migrants from the legal sphere does not make the problem disappear, we could argue. Being both unwanted and yet present in the nation-state, the irregular migrant is at the same time situated in the paradox of state sovereignty vis-à-vis respect for human rights. In all the three Scandinavian countries, this paradox appears in policy discourse. On the one hand, there is emphasis on criminalization, developing control mechanisms, deportation and on restrictive actions and measures in general. On the other hand, political actors and governments reproduce discourses of human rights.

A dominating tendency is to present irregularity as an individual choice. Staying in a country without the right to do so therefore challenges state sovereignty. Migrants are responsible agents and responsible for their own fate, which legitimizes restrictive policies and actions leading to disempowerment. As Halvar Andreassen Kjærre puts it in a Norwegian study on irregular migration, they (the irregular migrants) are «imagined as «free illegals» or «voluntary sufferers» through a language focusing on the possibilities of rational and «voluntary» choice» (Kjærre 2010: 235). Restrictive policies and disempowerment rarely have the effect that governments would believe them or like them to have (e.g. Brekke \& Søholt 2005; Engbersen, San \& Leerkes 2006); however, from the perspective of Schneider and Ingram they nevertheless send a powerful symbolic message that the state is in control and holds the power to decide who is deserving and who is not.

Shahram Khosravi has done a study on irregular migrants in Sweden. Also in his study, Agamben's homo sacer is the point of departure (Khosravi, 2006). Having an explicit normative agenda, he argues that irregular migration violates the state law but not a general sense of justice or general moral or ethical norms (ibid: 284). However, the states (in this case Sweden) have territorialized human rights and turned them into a nationstate system by reducing human rights to citizenship-based rights. This argument once more reproduces the central paradox outlined in this article. How can states articulate discourses on humanity and human rights while delimiting irregular migrants' rights? From a perspective on normative ethics, the governments act and justify their actions from something coming close to state consequentialist ethics that is based on the argument that an action is right and just if it leads to state stability. Hence, even if it entails using illiberal means, for example, deporting people without conducting a proper case investigation, the approach can be legitimized if it helps restoring social order.

Following Schneider and Ingram, however, the policy responses and embedded inequality comprise degenerative policy designs where policies firstly do not solve the alleged problems and secondly are characterized by injustice and ultimately are a far cry from democracy. Although the migrants are excluded from social and political rights, they are included (on an irregular basis) in the labour market (in Scandinavia also) providing a flexible, inexpensive labour force. As was stated in a parliamentary debate by Kalle Larsson member of Vänsterpartiet (Riksdagens Protokoll 2007/08:43: Anf. 33): «The hidden ones make it possible for us to eat hamburgers.»

This section on naming leads to the last part of this article where I look specifically into the problem of representations of irregular migration in the Scandinavian countries. 
Based on the former sections on how policy understandings are constructed and linked to a particular target group and constructions establishing distinctions between wanted/ unwanted, deserving/undeserving, citizens/non-citizens and included/excluded, I investigate how strategies of naming, framing and blaming are used to legitimize policy actions.

\section{Problem representations and categorizations in Scandinavia}

The problematization of irregular migration has been quite divergent in the Scandinavian countries. Although the political system in the three countries often are characterized as 'most similar' and have the same type of universal welfare state and political system, the approach to questions of migration (regular and irregular), asylum and integration have been less convergent (Brochmann \& Hagelund 2011; Jørgensen \& Meret 2012). Looking specifically at how irregular migration has been problematized and how irregular migrants have ended up as target groups, there has been surprisingly little attention to this area in Denmark, despite a very politicized and contested policy field on immigration issues. Sweden has already had several parliamentary debates and action plans on this issue since the EU Tampere Summit in 1999, which initiated the EU actions and policy developments on the same. Likewise Sweden has applied very different policy instruments (amnesty/regularization of irregular migrants as well as restrictions in entrance and rights), while Norway has placed itself somewhere in between, having political and public debates and seeking to balance national interests of sovereignty and humanitarian aspects.

In these three country cases, I will look specifically on access to health. The Scandinavian countries have ratified international conventions protecting (also) irregular migrants with basic human rights and access to health (Lægeforeningen, Dansk Røde Kors og Dansk Flygtningehjælp 2010; see also Cuadra 2011; European Union Agency for Fundamental Rights 2011). These include the Universal Declaration of Human Rights from 1948 as well as the covenants following later in 1966 and 1976. The Covenant on Civil and Political Rights, which came in force from 1976, is significant in the case of rejection of health services to irregular migrants on the basis of that category. Also The International Convention of the Rights of the Child, which went into force in 1990, offers entitlement of special safeguard and care for children irrespective of their status.

We briefly look at the divergences in the distribution of entitlements. In the three countries, irregular migrants can receive 'emergency care' but the countries differ in whether the recipient has to pay for the service or not.

The EU has directly and indirectly spurred particular policy frames and problematizations, which later have been transposed, interpreted and adopted, by the Scandinavian countries in different ways. The EU has also been responsible for drawing up new, competing frames (i.e. frames that deliberately seek to challenge the dominating problem formulation of irregular migration) like for instance putting more responsibility on the employers (of irregular migrants) and less on the migrants themselves, which was stipu- 
lated in the Employer Sanctions Directive (European Parliament and the Council of the European Union 2009). In the following brief sections, I look at the three countries and examine the underlying assumptions behind the problem representations (cf. Bacchi) in order to understand how a particular policy approach is legitimized.

\section{Norway}

Norway has a special position as it is not a member of the EU but has joined both the Schengen framework and the Dublin regulations. This means in practice that it has to follow most of the EU framework stipulations on asylum and migration issues. Norway took irregular migration to a public level of debate fairly late. In 2008, the government commissioned a study providing the extremely precise calculation that 18,196 irregular migrants lived in Norway (Zhang 2008). What was perhaps more important than the total number, is that, according to the repost, two thirds were rejected asylum seekers. The equivalence between irregular migrants and asylum seekers has since influenced the debates on irregular migration and appropriate actions. It leads to quite different problematizations.

One policy problematization claims that asylum seekers should be protected no matter the outcome of their case and hence emphasizes the humanitarian aspects. The other problematization claims that no one will benefit from the fact that somebody decides to remain in the country without the required papers. The underlying assumption here is that it will undermine the whole system and even reduce the possibilities of 'genuine' asylum seekers being granted protection (Justis og Politidepartementet 2011). The main approach is to create better life conditions for irregular migrants living in Norway, while at the same time discouraging irregular migration by ensuring that return policies are enforced, for instance, while also creating better life conditions for irregular migrants living in Norway. The government led by Jens Stoltenberg since 2005 (comprised by the Labour Party, Socialist Left Party and Centre Party) has used the notion of 'fair but firm' policies. The notion goes back to the so-called Soria-Maria declaration from 2005. The declaration was a policy paper developed by the newly elected government coalition between the Norwegian Labour Party, the Socialist Left Party and the Centre Party on matters of asylum policies (Regjeringen 2005). The declaration established bilateral return agreements so that rejected asylum seekers could be deported. At the same time, it wanted to look at the life conditions of foreigners living in Norway without legal permits - seeking to improve human conditions for those whose demands for asylum were rejected but who had not left the country. However, the effects of the declaration may be the same no matter the intention - that irregular migrants disappear from the authorities to avoid being deported.

This attempt to balance between humanitarian concerns and restrictive measures also shows up in the labeling of irregular migrants. The term illegal is used to describe formal conditions such as mode of entry and residence status, whereas irregular is used when speaking of individuals (Jørgensen \& Meret 2012). The preference of the different notions can also be traced in the political cleavage structure. The notions 'paperless' and 'undo- 
cumented' is preferred by the Socialist Left, the Liberal Party and the Christian Democratic Party, whereas the Progress Party consistently prefer to use the term 'illegals'. Categorization has consequences. Whereas the Progress Party positions the irregular immigrants among the deviant and undeserving, the use of paperless oppositely opens up for investigating exactly what kind of rights these people in reality have.

Questions of access to health services and treatment have been debated over the last years. Since January 2012 health care has been restricted to now only covering situations of life and death or vital damages. This can be seen as violating the human rights and calls for a discussion of the moral obligations a state has toward non-citizens (see Sinding Aasen \& Kjellevold 2012).

\section{Sweden}

Sweden has by far had the most comprehensive debate on irregular migration when comparing the three countries. It has been a reoccurring theme in parliamentary debates since at least 1999. As in Norway, the discussion revolves around a distinction between humanitarian principles vis-à-vis upholding the system and holding on to national discretion. Sweden is a full member of the EU and has implemented all the directives coming from the EU Commission on asylum and migration issues. This has in itself spurred strong debates. For instance, the implementation of the Return Directive caused serious debate as many politicians saw it as an example of inhuman practices only serving to criminalize migrants (Spång 2007). Helping people on humanitarian grounds should not be punishable as the directive otherwise leads to.

There have been lengthy discussions about the labelling of irregular migrants and almost all possible notions have been employed at one time or the other. What is interesting is that the conceptual discussions, which also take place in the parliament, are connected to a very conscious idea about the potential policy actions and instruments following from a particular notion. Compared to the two other countries, Swedish politicians have taken more explicit positions than the often vague positions claimed by politicians in the two other countries (apart from populist parties). In 2000, the then Minister of Justice gave a very straightforward answer to the question 'what is implied in the category illegal person?': «a person who applies for asylum cannot be defined as illegal immigrant, no matter how he has arrived in the country where he applies for asylum» (Riksdagens snabbprotokoll 2000/01: 34). The problem of representation is therefore that it is not the migrants who constitute the real problem, but rather the legal framework constructing people as illegal. The Swedish government therefore is prompted to fight for standard rights within the EU. That position has been defended over the years by shifting political parties and lies rather far from construction of the non-citizen, homo sacer.

However, this position is also only one of many as and like in Norway and recently in Denmark, there has been a strong problem representation stating that people staying illegally and not contributing to society should not enjoy the same rights as citizens. From this problem representation, it can be seen that what is needed is efficient management of deportation rules for instance. Conversely, one could argue that, if Sweden is in need of 
labour, it should not come from irregular migrants who undermine the system but from liberalizing the labour market regulations and access to the country (Jørgensen \& Meret 2012). The competing problem representations in this sense creates a distinction between legalization (due to exploitation, human rights, no person is illegal) or at least access to health and school vis-à-vis respecting the asylum procedures and regulations.

A particular feature in Sweden, however, is the role of the trade unions, which have been strong advocates for more restrictions and increased control. Subsequently, there is a divergence between the political rhetoric and what can be found elsewhere in Swedish society. The trade unions draw on conventional assumptions stating that irregular migrants undermine the welfare state (Khosravi 2006). Irregular migrants in this representation are breaching the law, straining the welfare system and are immoral persons. They constitute a labour market problem as they take away jobs from regular citizens (being cheap, flexible and outside the collective bargaining agreements) and thereby constitute a threat to national identity. Within this frame irregular migrants are constructed as deviants who do not belong in Sweden and should be punished and ultimately deported. The migrants are the ones to blame. This stands in contrast to the other frame that claims that the EU framework is to be blamed.

When it comes to access to health and questions of entitlement to treatment, it has been an ongoing parliamentarian discussion if irregular migrants should or could have rights and access to health care (Riksdagens protokoll 2007/08:105).

\section{Denmark}

As mentioned, irregular migration has been given little attention in Denmark until recently. The underlying explanations have been that the Danish labour market is difficult to enter without papers. The same goes for the social system, which is dependent on the person having a social security number. It is a country located far from the main transit hubs into Europe, yet recent studies have shown that irregular migrants live and work in Denmark as elsewhere in Scandinavia (Thomsen et al. 2010). From being an almost invisible target population estimated to number 1,000-5,000, the police taskforce now estimates that there are between 20,000 and 50,000 irregular migrants in the country (Glerup 2012; Kejser \& Scharling 2012). The estimate is not based on any research project or new methodology, but on three interviews with anonymous sources within the police and should at best be considered a guestimate (Glerup 2012). Disregarding what the actual number could be, what is interesting here are the underlying assumptions supporting the representation of irregular migration. The labour unions alongside some politi-

cal parties have since the enlargement of the EU with the first ten Eastern European countries called for more control and restrictions to protect the Danish labour market. The problematization has now expanded to encompass at least four main 'problems' related to irregular migration: As a question related to security; straining the public welfare budget; increased levels of crime and social dumping (see for instance Dansk Politi 2012). This constructs a target group depicted solely by negative and damaging attributes. It places all responsibility and blame on the irregular migrants and completely 
avoids encompassing, for instance, human exploitation. It therefore legitimizes further control mechanism and harsher actions and methods to combat what is perceived to constitute a threat to society.

The dominating labelling of irregular migrants is 'illegal', leaving less emphasis on the humanitarian aspects, which characterizes the problematization in Norway and in Sweden as well. This labelling is used by all political parties, albeit with different rationales. For the right-winged parties, their presence is understood as breaching the law whereas the left-winged parties have been mainly concerned about their position on the labour market and the impact on the legal and organized labour force. NGOs and civil society organizations use other terms legitimizing other policy approaches, for example, referring to them as undocumented, calling for a legalization of their status.

The rather weak focus on irregular migration by the authorities combined with the introduction of only few policy actions can be explained as a deliberate strategy of nonaction. States can act in other ways than making actual decisions (followed by actions). As Peter Bachrach and Morton Baratz argued already in 1963, decision making involves not only actual active decisions but also non-decision making (Bachrach \& Baratz 1963). They define non-decision making as «the practice of limiting the scope of actual decisionmaking to «safe» issues by manipulating the dominant community values, myths, and political institutions and procedures» (ibid: 632) they continue by stating that: «To pass this over is to neglect one whole «face» of power» (ibid). Bachrach \& Baratz refute the objection that non-decisions are non-events that cannot be observed. If we look at the decision making concerning irregular migration, we find that it is a practice used in different ways and for different purposes. It is a way to silence a highly contested issue.

So for instance, in Denmark the category 'assumed departed' used by the police is used for all irregular migrants and asylum seekers (still in the assessment process and rejected) who disappear from the authorities (Rigspolitiets Nationalt Udlændingecenter 2011). In reality, there is little evidence - if any at all - supporting that these persons have actually left the country and as they constitute a vulnerable group without material resources it is indeed extremely difficult to imagine where they would go. In Sweden, the police also keep numbers on people disappearing from the reach of the authorities. However, in contrast to the Danish practice, they believe that the disappeared persons have «gone below» the radar and provide for themselves on the clandestine labour market (Jørgensen \& Meret 2010). Using the category 'assumed departed' makes it possible for the government and authorities not to take specific actions - simply because the problem is constructed not to be there. Non-action also happens on another level when authorities pay little attention to employees in the service sector, which has shown to be one of the markets for irregular labour. By comparison, there is much attention being paid to the building sector where the unions have been far more active in assisting the authorities and to some degree have been the main drivers. Hence, it is not only a question of what states do but also a question of what states do not do.

In case of healthcare, in Denmark, treatment is free of cost whereas it has to be paid by the recipient in Sweden. In principle, however, the irregular migrants are living in insecurity in all three countries, not knowing what kind of services they are entitled to or if 
they will be apprehended by the police. The obligation to offer access to health services is juridical, but from the perspective of NGOs and stakeholders from the health providers it is also a moral obligation (e.g. Dagens Medicin 2011). Yet, it is an ongoing debate and a policy field characterized by a combination of non-decision and extremely slow developments as it is situated exactly in the paradox about the sovereignty of the nation-state visà-vis human rights regimes. The Danish state, for instance, chose not to act, made a nondecision when a private health clinic offering services to irregular migrants opened in 2011. The Danish People's Party wanted the police to guard the clinic and arrest visitors with an irregular status, however, the then Minister of Health decided not to act (JyllandsPosten 2011).

Concluding the Danish approach, we can say that Denmark compared to the other two countries has put very little emphasis on irregular migration. There have been no attempts to collect data on the number of irregular migrants residing in Demnark, for instance. There has been most focus on irregular migrants on the labour market and especially the labour migrants from the East European Member States of the EU working under irregular conditions in Denmark. Only recently has it been acknowledged that there might be - or indeed is - a far more diverse group of irregular migrants in the country. The fact that the authorities in 2011 had no register of the 7,500 persons who had sought asylum in Denmark in the preceding five years had been ignored. Only last year this number was connected to the issue of irregular migration and action was called for (Politiken 2011).

\section{Summing up}

The approaches to irregular migration differ from country to country. Generally, Sweden engages in the EU development more explicitly than the other two countries. Norway follows the development, whereas, EU has less impact on parliamentary debates in Denmark aside from the security dimension and control mechanisms, which are evaluated positively as long Denmark can keep its opt-out from initiatives it does not like. Norway and Sweden have both applied similar problem frames seeking to at the same time wanting to stay in control while also respecting humanitarian values. Sweden has emphasized the latter more whereas Norway has drawn on the first framing; however, both components can be found in both countries. Denmark has applied a different frame, which more or less has ignored the phenomenon meaning that the issue of irregular migrants until recently has played a minor role. Framing has mainly pertained to labour market conditions. As regards categorization, in Denmark the category of 'assumed departed' illustrates the aforementioned frame. In both Sweden and Norway, different categories have been used to stress the particular aspect of the articulated frame: illegals when it comes to issues of control and irregulars when it comes to humanitarian aspects. In Sweden, there has been a preference for the latter categorization.

In all three countries, skeptics of immigration and to some degree right-wing parties have employed the category of illegal whereas the left-wing parties have named the migrants as irregular. Who's to blame? Again we can identify similarities following the 
political cleavage structures. Immigrant-skeptical parties would locate the responsibility in the migrants themselves. They are understood to be rational actors making deliberate choices and hence can stand as responsible for those actions. In Sweden there has been emphasis on the responsibility of the employers and there have been used moral arguments saying that everyone in Swedish society take benefit of the work performed by the irregular migrants.

Access to health services and treatment is perhaps the litmus test for democracy and one of the areas of rights that are secured through international conventions as outlined in the beginning of this section. In the three countries, treatment is offered in different ways and under certain conditions. When to be able to treat a patient is a grey-zone as medical personnel at all levels do not have clarity when exactly they are allowed to treat irregular migrants in the public system or how 'emergency care' should be defined, but in this aspect the government also opted for non-decision as the main strategy. As Khosravi (2006) has argued, however, the main tendency has so far been a territorialization of the human rights implying that the international conventions are given national interpretations and limitations.

\section{Conclusion}

In this article, I have made an attempt to show how particular problem problematizations legitimize particular policy frameworks and policy tools, rules and regulations. Irregular migrants are constructed as a negatively defined target population either living on the fringe of society or outside it completely. Naming irregular migrants as illegal positions them as non-citizens and strips them of rights and entitlements they otherwise should be eligible for. Framing the issue of irregular migration as an individual choice likewise legitimizes restrictive policy measures as no one asked the migrants to take up residency in the countries. While it is easy to identify these exclusionary mechanisms, it is less easy to come up with a solution. Irregular migration enters into the middle of the distinction between national discretion and sovereignty vis-à-vis respecting human rights. This can also be recognized in the way that the countries deal with related issues of migration, asylum and integration and ultimately issues pertaining to national identity.

This dilemma also provides an explanation for divergence, for example, explicitly addressing the issue (Sweden and Norway) or not (Denmark), making use of legalization (Sweden only), placing responsibility on the migrants (all the countries) and/or on employers (Sweden), emphasizing the humanitarian aspects (especially Sweden and Norway), which can be found among the Scandinavian countries that otherwise resemble each other in many aspects. The territorialization of human rights, which reduce human right to national citizenship-based rights, opens up for these types of divergences. In this article I have sought to outline some of them.

Despite lacking the required papers and legal right to stay, irregular migrants still have fundamental human rights. When the governments in order to please immigrant-skeptical populations disregard these rights, they end up creating an exclusionary universalism 
standing in contrast to the basic idea of the welfare state. Excluding irregular migrants from basic rights and provisions, such as healthcare and access to school, and emphasizing control mechanisms, such as deportation and criminalization, regardless of the situation in the countries, of origin of the irregular migrants, is a serious threat to substantive democracy (cf. Schneider \& Ingram 1997). Singling out particular groups in the society as a moral and financial burden while at the same time ignoring that they fill a position in a segregated labour market, and only can do so because somebody employs them and even more people take advantage of the services they perform, also stands as a challenge to modern-day democracies. Principles of equity, justice and fairness are sacrificed due to the division between deserving and undeserving groups. Irregular migrants belong to he latter, regardless of their personal trajectories and contribution to society. Looking at these migrants as wasted lives and working poor and therefore undesirable legitimizes coercive policy tools and provides justification for punitive tools.

From a normative theoretical perspective, I have argued that the construction of a deviant target populations may strengthen the 'problems' rather than solve them, and strengthen the gap between deserving and undeserving groups. This not only creates gaps between different groups in society, but also contributes to eroding substantive democracy. Such degenerative policy designs will legitimize over-subscribing burdens to weak and deviant target populations and subjecting non-citizens to exclusivist policy measures. The European Union has as an example been active in creating a framework that removes the incentives for hiring irregular migrants by penalizing employers of irregular migrants (the Sanctions Directive); this approach has not been implemented efficiently in the Member States. The hegemonic problematization of irregular migrants is still that they are ones to blame and those who should be criminalized and punished. They constitute the undeserving target population. For a large part of the population it would not make sense to make their position better by criminalizing (national) citizens. For advantaged target populations like the employers, burdens will remain undersubscribed.

\section{Notes}

1 In this article I use the concept irregular migrant/migration as I follow the scholarly claim that it is not the person who is illegal but the laws making the act illegal. When other concepts are used in the empirical cases I use the employed terms in that specific context.

2

In 2010 the 25 years' old Russian born Madina Salamova published a book under the pseudonymous of Maria Amelie, titled Illegal Norwegian (Norwegian: Ulovlig norsk). In the book she describes her life as irregular immigrant in Norway. In January 2011 she was apprehended by the Norwegian police and deported to Russia. The decision of the Norwegian authorities spurred public debate.

\section{Literature}

Agamben, G. (1995) Homo Sacer: Sovereign Power and Bare Life. Stanford: Stanford University Press. 
Agamben, G. (2005) State of Exception. Chicago: University of Chicago Press.

Amnesty International (2010) Denmark - Human rights violations and concerns in the context of counter-terrorism, immigration-detention, forcible return of rejected asylum-seekers and violence against women. Submission to the UN Universal. Retrieved $15^{\text {th }}$ October 2012 from: http:// www2.ohchr.org/english/bodies/hrc/docs/ngos/AI_Denmark_November2010.pdf

Bacchi, C. (2009) Analysing Policy: What's the problem represented to be? Pearson: Australia.

Bachrach, P. \& Baratz, M. S. (1963) Decisions and nondecisions: An analytical framework. The American Political Science Review, 57 (3), pp. 632-642.

Bauman, Z. (2004) Wasted Lives. Modernity and its Outcasts. Cambridge: Polity Press.

Brekke, J-P. \& Søholt, S. (2005) I velferdsstatens grenseland: En evaluering av ordningen med bortfall av botilbud i mottak for personer med endelig avslag på asylsøknade [In the Border-land of the Welfare State: An evaluation of the scheme with the loss of housing for people in receipt of a final rejection of the asylum]. Oslo: Institute for social research.

Brochmann, G. \& Hagelund, A. (2011) Migrants in the Scandinavian welfare state. The emergence of a social policy problem. Nordic Journal of Migration Research, 1 (1), pp. 13-23.

Castles, S. (2003) Towards a sociology of forced migration and social transformation. Sociology, 1, pp. 13-34.

Cuadra, C.B. (2011) Right of access to health care for undocumented migrants in the EU: a comparative study of national policies. European Journal of Public Health, 22 (2), pp. 267-271.

Dagens Medicin (2011) Illegalt? [Illegal?] Dagens Medicin, 26 ${ }^{\text {th }}$ August 2011.

Dansk Politi (2012) Derfor er illegale et problem [This is why illegals are a problem]. Dansk Politi, no. $3 / 2012$.

Engbersen, G., San, M. van \& Leerkes, A. (2006) A room with a view: Irregular immigrants in the legal capital of the world. Ethnography, 7 (2), pp. 209-242.

European Parliament and the Council for the European Union (2009) Directive 2009/52/EC of the European Parliament and of the Council of 18 June 2009 providing for minimum standards on sanctions and measures against employers of illegally staying third-country nationals. Brussels: European Parliament and the Council for the European Union.

European Union Agency for Fundamental Rights (2011) Migrants in an irregular situation: access to healthcare in 10 European Member States. Vienna: European Union Agency for Fundamental Rights.

European Union Agency for Fundamental Rights (FRA) (2011) Fundamental rights of migrants in an irregular situation in the European Union. Lastet ned fra: http://fra.europa.eu/en/publication/2012/fundamental-rights-migrants-irregular-situation-european-union

Glerup, M.R. (2012) Ingen kender tal for illegale indvandrere [No one knows the number of illegal immigrants]. Retrieved $15^{\text {th }}$ October 2012 from: http://www.dr.dk/P1/Detektor/Udsendelser/ 2012/05/01170052.htm

Guild, E. (2004) Who is an illegal migrant? In Irregular Migration and Human Rights: Theoretical, European and International Perspectives, eds. B. Bogusz, R. Cholewinski, A. Cygan \& E. Szyszczak, pp. 3-28. Leiden: Martinus Nijhoff Publishers.

Hjelde, K.H. (2010) Irregular migration, health and access to health services in Oslo. In Irregular Migration in a Scandinavian Perspective, eds. T.L. Thomsen, M.B. Jørgensen, S. Meret, K. Hviid \& H. Stenum, pp. 319-340. Maastricht: Shaker Publishing.

Jordan, B. \& Düvell, F. (2003) Migration - The Boundaries of Equality and Justice. Cambridge: Polity Press.

Justis og Politidepartementet [Ministry of Justice and Public Security] (2011) Prop. 1S (20112012), Proposisjon til Stortinget (Forslag til Stortingsvedtak) [Proposition to the Storting (parliament Proposed Decision).]. Oslo: Ministry of Justice and Public Security. 
Jyllands-Posten (2011) Nu åbner lægeklinik for illegale indvandrere [Now opens a medical clinic for illegal immigrants]. Jyllands-Posten, $11^{\text {th }}$ August 2011.

Jørgensen, M.B. \& Meret, S. (2010) Irregular migration from a comparative Scandinavian policy perspective. In Irregular migration in a Scandinavian Perspective, eds. T.L. Thomsen, M.B. Jørgensen, S. Meret, K. Hviid \& H. Stenum, pp. 121-152. Maastricht: Shaker Publishing.

Jørgensen, M.B. \& Meret, S. (2012/forthcoming) Framing Scandinavian migration regimes in a European context. Nordic Journal of Migration Research, 3 (4).

Kejser, T. \& Scharling, N. (2012) Ingen kontrol med falske identiteter [No control with false identities]. Dansk Politi, $29^{\text {th }}$ March 2012.

Khosravi, S. (2006) Territorialiserad mänsklighet: Irreguljära immigranter och det nakna livet. Om välfärdens gränser och det villkorade medborgarskapet [Territorialiserad humanity: irregular immigrants and bare life. On welfare limits and the conditional citizenship]. Statens offentliga utredningar 2006:37, pp. 283-310. Stockholm: Arbetsmarknadsdepartementet.

Kjærre, H.A. (2010) No direction home - the margins of a welfare state and the illegalised body. In Irregular Migration in a Scandinavian Perspective, eds. T.L. Thomsen, M.B. Jørgensen, S. Meret, K. Hviid \& H. Stenum, pp. 231-257. Maastricht: Shaker Publishing.

Koser, K. (2005) Irregular migration, state security and human security. Global Commission on International Migration.

Lægeforeningen, Dansk Røde Kors og Dansk Flygtningehjælp (2010) Udokumenterede migranters adgang til sundhedsydelser $i$ Danmark [Undocumented migrants' access to health services in Denmark]. Notat, december 2010.

Politiken (2011d) Afviste udlændinge lever skjult i Danmark [Rejected foreigners live hidden in Denmark]. Politiken, $31^{\text {st }}$ January 2011.

Regjeringen (2005) Plattform for regjeringssamarbeidet mellom Arbeiderpartiet, Sosialistisk Venstreparti og Senterpartiet 2005-09. Retrieved 15 ${ }^{\text {th }}$ October 2012 from: http://www.regjeringen.no/upload/SMK/Vedlegg/2005/regjeringsplatform_SoriaMoria.pdf

Rigspolitiets Nationalt Udlændingecenter (2011) Status på arbejdet med udsendelse af afviste asylansøgere. Copenhagen: Rigspolitiet [National Police].

Riksdagens protokoll [Parliamentary Protocol] 2007/08:43 Torsdagen den 13 december. Stockholm: Sveriges Riksdag.

Riksdagens protokoll [Parliamentary Protocol] 2007/08:105 Tisdagen den 6 maj. Stockholm: Sveriges Riksdag.

Riksdagens snabbprotokoll [Parliamentary Brief Protocol] 2000/01:34.

Schneider, A.L. \& Ingram, H.M. (1997) Policy Design for Democracy. University Press of Kansas.

Schneider, A.L. \& Ingram, H.M. (2005) Introduction: Public policy and the social construction of deservedness. In Deserving and entitled: Social constructions and public policy, eds. A.L. Schneider \& H.M. Ingram, pp. 1-28. Albany: State University of New York Press.

Sinding, H.A. \& Kjellevold, A. (2012) Velferd og menneskerettigheter: «Ulovlig opphold» som grunnlagfor å avskjærehelse-og sosialhjelp? [Welfare and Human Rights: «Illegal residence» as a basis for precluding health and social services?] Tidsskrift for velferdsforskning, 15 (2), pp. $93-$ 108.

Soss, J. (2005) Making client and citizens: Welfare policy as a source of status, belief, and action. In Deserving and Entitled: Social Constructions and Public Policy, eds. A.L. Schneider \& H.M. Ingram, pp. 291-328. Albany: State University of New York Press.

Spång, M. (2007) Sweden: Europeanization of policy but not of politics? In The Europeanization of National Policies and Politics of Immigration, eds. T. Faist \& A. Ette, pp. 116-135. Basingstoke: Palgrave. 
Stenum, H. (2010) Workers and vagrants: Governing the foreign poor in Denmark. In Irregular Migration in a Scandinavian Perspective, eds. T.L. Thomsen, M.B. Jørgensen, S. Meret, K. Hviid \& H. Stenum, pp. 205-230. Maastricht: Shaker Publishing.

Thomsen, T.L., Jørgensen, M.B., Meret, S., Hviid, K. \& Stenum, H. (eds.) (2010) Irregular migration in a Scandinavian Perspective. Netherlands: Shaker Publishers.

Triadafilopoulos, T. (2011) Illiberal means to liberal ends? Understanding recent immigrant integrating policies in Europe. Journal of Ethnic and Migration Studies, 37 (6), pp. 861-880.

UNHCR (2010) Concerned at ongoing deportations of Iraqis from Europe. Briefing Notes, 3 September 2010. Retrieved $15^{\text {th }}$ October 2012 from: http://www.unhcr.org/4c80cad89.html

Wacquant, L. (2009 [2004 original in French]). Punishing the Poor. The Neoliberal Government of Social Insecurity. Durham: Duke University Press.

Zhang, L-C. (2008) Developing methods for determining the number of unauthorized foreigners in Norway. UDI FoU Report, 1. Oslo: Statistics Norway. 